\title{
Yhteisymmärryksen rakentaminen monikulttuurisilla lääkärin vastaanotoilla
}

\author{
JENNY PAANANEN
}

\section{Väitöksenalkajaisesitelmä Turun yliopistossa 15. maaliskuuta 2019}

Lääkärin työkaluja kuvataan usein iskulauseella "puhe, puukko ja pilleri”. Yleislääkärin työssä tärkein näistä kolmesta lienee puhe. Käytännössä koko vastaanottotapahtuma rakentuu puhumisen varaan: käynnin syyn selvittäminen, vaivan diagnosointi sekä jatkotoimenpiteistä ja hoidosta päättäminen tapahtuvat keskustelemalla. Näin ollen puukkoon ja pilleriin on tarkoitus päätyä vasta sitten, kun niistä on ensin puhuttu. Mutta kuinka lääkäri ja potilas pääsevät yhteisymmärrykseen silloin, kun he ovat kotoisin eri maista ja puhuvat eri äidinkieltä? Tätä olen pyrkinyt väitöskirjassani selvittämään.

Vielä vuosituhannen alussa tutkimuskysymykseni olisi voitu tulkita hypoteettiseksi, harvinaislaatuisia tapauksia koskevaksi kysymykseksi. Tämän päivän Suomessa kysymys on kuitenkin relevantti ja ajankohtainen, sillä joka neljästoista Suomessa asuva on ulkomaalaistaustainen, ja maahanmuutto kasvattaa osuutta jatkuvasti. Maahanmuuttokeskustelu on viime aikoina painottunut pakolaiskriisiin ja sen hoitamiseen, mutta meneillään on paljon muutakin. Suomi on tällä hetkellä monella tapaa riippuvainen maahanmuutosta. Elämme tilanteessa, jossa väestö ikääntyy ja huoltosuhde heikkenee. Kuolleisuus on viime vuosina ollut Suomessa suurempaa kuin syntyvyys. (SVT 2018.) Suurten ikäluokkien eläköityminen aiheuttaa työvoimapulaa. Terveydenhuollossa työvoimapula näkyy kahdella tavalla: työtä tekevien määrä pienenee samalla kun hoidettavien määrä kasvaa. Niinpä Suomeen saapuu ja hankitaan työvoimaa ulkomailta. Ulkomaalaistaustaisella työvoimalla paikataan esimerkiksi juuri lääkärivajetta, ja lääkäreissä on jo tällä hetkellä suhteessa enemmän ulkomaalaistaustaisia kuin koko väestössä (Lääkäriliitto 2017).

Monikulttuuristuminen kuitenkin myös huolestuttaa, ja sen vaikutuksia sosiaalija terveyspalvelujen laatuun on pyritty selvittämään erilaisin kysely- ja haastattelututkimuksin. Useissa niistä on käsitelty kieli- ja kulttuurieroihin kytkeytyviä ongel- 
mia. (Ks. esim. Aalto, Elovainio, Heponiemi, Hietapakka, Kuusio \& Lämsä 2013; Malin \& Suvisaari 2010; Tervola 2017.) Yhteisymmärryksen rakentaminen näyttää olevan monikulttuurisissa vuorovaikutustilanteissa tavallista työläämpää, mikä koettelee luottamuksen syntymistä. Luottamuspula taas johtaa siihen, ettei vastaaviin tilanteisiin haluta uudelleen. Rakentuu mielikuvia huonoista lääkäreistä, vaikeista potilaista ja epäilyttävistä tulkeista. Osa potilaista valittaa, osa jättäytyy palvelujen ulkopuolelle (esim. Malin \& Suvisaari 2010: 147-148). Suomen nykyisessä asenneilmastossa negatiivisista kokemuksista on valitettavan lyhyt matka suoranaiseen syrjintään. Kyselytutkimusten perusteella sekä maahanmuuttajalääkärit että maahanmuuttajapotilaat kohtaavat Suomessa epäasiallista kohtelua (Aalto ym. 2013: 64; Castaneda, Larja, Nieminen, Jokela, Suvisaari, Rask, Koponen \& Koskinen 2015: 18). Vuorovaikutukseen liittyvää koulutusta pidetään yleisesti riittämättömänä.

Monikulttuurista vuorovaikutusta on kuitenkin vaikeaa parantaa vain sen perusteella, mitä kohtaamisista jälkikäteen kerrotaan. Kokemus vuorovaikutuksen sujumisesta tai sujumattomuudesta on henkilökohtainen, ja siihen vaikuttavat hyvin monenlaiset seikat. Väitöskirjassani tarkastelenkin vuorovaikutusta analysoimalla videoituja yleislääkärin vastaanottoja, joilla joko lääkäri tai potilas on ulkomaalaistaustainen ja puhuu äidinkielenään muuta kuin suomea. Lähestymistapani poikkeaa aiemmista tutkimuksista myös siten, etten ole pyrkinyt kartoittamaan vuorovaikutuksen ongelmia vaan keinoja, joilla kieli- ja kulttuurieroista mahdollisesti aiheutuvia ongelmia pyritään ehkäisemään ja ratkaisemaan. Olen tutkinut, millaisia kielellisiä ja kehollisia resursseja monikulttuurisilla vastaanotoilla käytetään ja mitä näiden keinojen käyttäminen tilanteista kertoo. Lisäksi olen pohtinut yhteisymmärryksen rakentamisen tapaa suhteessa lääkärin vastaanoton institutionaaliseen kontekstiin.

Olen kerännyt tutkimusaineistoni itse ja viettänyt siten aikaa terveysasemilla ja tavannut kaikki tutkimukseen osallistuneet ihmiset. Kenttätyö on syventänyt ymmärrystäni tutkimuksen aiheesta ja tuonut tutkimukseeni etnografista sävyä. Tutkimukseni varsinaiset metodit, joilla videoaineistoa analysoin, ovat keskustelunanalyysi ja vuorovaikutuslingvistiikka, joissa molemmissa vuorovaikutuksen yksityiskohtia tarkastellaan aineistolähtöisesti ja laadullisesti. Keskustelunanalyysin avulla lähestyn vastaanottovuorovaikutuksen jäsentymistä ja toimintoja, kuten kysymistä ja vastaamista ja päätöksistä neuvottelua. Vuorovaikutuslingvistinen ote taas näkyy kielellisten yksityiskohtien analyysissa, mikä on erityisen olennaista silloin, kun tarkoituksena on tutkia kielieron näkymistä ja vaikutuksia keskustelussa. Olen esimerkiksi kiinnittänyt huomiota sanavalintoihin ja lauserakenteisiin ja tutkinut, miten vuorovaikutuksen toimintoja muotoillaan kielellisesti. Kuinka kysytään ja kuinka selitetään? Millaisin kielellisin elementein signaloidaan, että ollaan tekemässä päätöksiä? Videoaineiston johdosta olen myös voinut katsoa, mitä vastaanotoilla tapahtuu fyysisesti: mitä osallistujat tekevät, miten he liikkuvat tilassa ja mitä he katsovat.

Väitöskirjani koostuu viidestä osajulkaisusta, joissa lähestyn yhteisymmärryksen rakentamista varsin erilaisista näkökulmista käsin. Olen tutkinut eleiden käyttöä (Paananen 2015), puheen uudelleenmuotoilua (Paananen 2016), selittämistä (Paananen 2017), tulkattua lääkäri-potilas-vuorovaikutusta (Paananen \& Majlesi 2018) ja päätöksistä keskustelemista (Paananen 2018). Osa tutkimusaiheista on noussut esiin ai- 
neistosta, ja osa on syntynyt aiempien tutkimusten havaintojen ja yhteiskunnallisen keskustelun kautta. Tutkimustani voi näin ollen pitää kulttuurisesti kontekstoituna keskustelunanalyysina. Olen tietoisesti pyrkinyt ymmärtämään tutkimaani aihetta laajasti ja käsittelemään myös sellaisia kysymyksiä, jotka eivät aineiston perusteella välttämättä nousisi esiin mutta joiden tarkasteleminen on yhteiskunnallisesta näkökulmasta tärkeää. Esimerkiksi potilaan huomioimista päätöksenteossa ja tulkatuilla vastaanotoilla olen tarkastellut ennen kaikkea aiheeseen liittyvän yleisen huolen vuoksi.

Tutkimukseni osoittaa, että kieli- ja kulttuurierot pyritään huomioimaan vuorovaikutuksessa monin tavoin. Lääkärit, potilaat ja tulkit virittäytyvät toisiinsa ja rakentavat yhteistä kielellistä ja kehollista ilmaisuvarantoa.

Kaikille yhteinen ja erityisen yleinen yhteisymmärrystä tukeva resurssi aineistossani on eleiden käyttö. Lääkärit, potilaat ja tulkit tukevat kielellistä ilmaisuaan esittävillä ja osoittavilla eleillä. Lääkärin vastaanotto onkin jo puheenaiheiden puolesta otollinen konteksti keholliselle ilmaisulle, sillä sairauteen, terveyteen, tutkimuksiin ja hoitoon liittyvät asiat koskevat usein kehoa, ja niitä on siten helppoa kuvata eleillä.

Aineistossani eleillä havainnollistetaan sanottua ja paikataan sanastollisia aukkoja. Eleitä käytetään osana selityksiä, ja niillä parannetaan ymmärrettävyyttä myös silloin, kun puhetta joudutaan muotoilemaan uudelleen. Lisäksi eleiden käyttö voi saada aikaan empaattisen vaikutelman. Näin tapahtuu esimerkiksi silloin, kun lääkäri ja tulkki ilmentävät potilaan kehoon liittyviä asioita oman kehonsa kautta vaikkapa koskettamalla rintaansa puhuessaan potilaan ahdistuksesta. Tällaiset eleet saattavat myös olla peräisin potilaalta itseltään, jolloin eleen toistaminen eli peilaaminen toimii viestinä ymmärtämisestä ja mukana olemisesta. Tulkatuilla vastaanotoilla eleen toistaminen tekee myös alkuperäisen vuoron ja tulkkeen yhteyden näkyväksi, mikä mahdollistaa tulkkauksen etenemisen seuraamisen ja voi siten myös lisätä luottamusta tulkkausta kohtaan.

Yhteisymmärrystä tuetaan myös erilaisin kielellisin keinoin. Esimerkiksi suomea äidinkielenään puhuvat lääkärit artikuloivat selkeästi, käyttävät yleistajuista sanastoa ja yksinkertaisia rakenteita ja selittävät käyttämiään ilmauksia usein oma-aloitteisesti kommunikoidessaan maahanmuuttajapotilaiden kanssa. Kun keskustelussa ilmenee mahdollisesti ymmärtämiseen liittyviä ongelmia, lääkärit reagoivat selkeyttämällä puhetta voimakkaammin, kuten seuraavassa kysymyksen muotoiluun liittyvässä esimerkissä (L: lääkäri, suomi; P: potilas, italia):

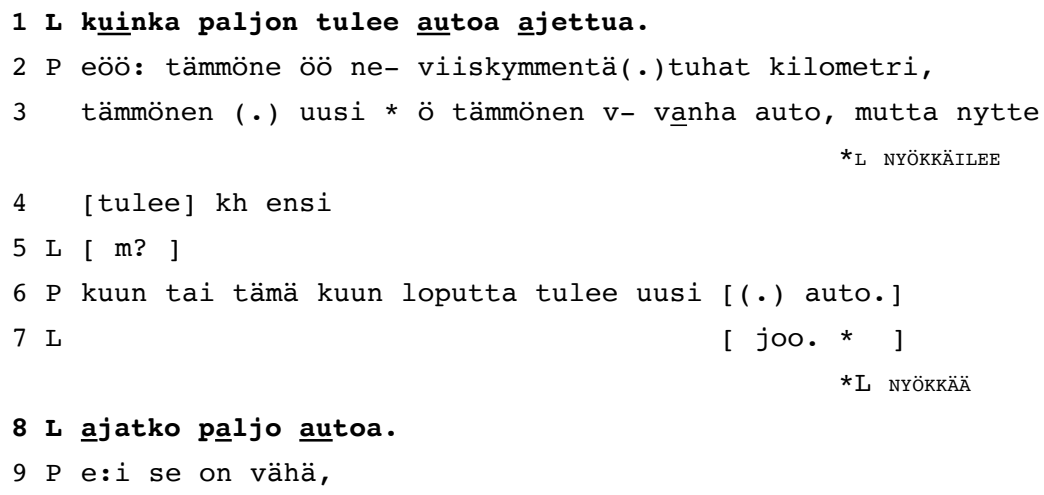


Esimerkin potilas on saapunut vastaanotolle saadakseen lääkärintodistuksen terveydentilastaan ajokortin uusimista varten. Lääkäri pyrkii kartoittamaan, kuinka paljon potilas ajaa, ja kysyy avainsanoja painottaen kuinka paljon tulee autoa ajettua. Potilas alkaa kuitenkin kertoa, kuinka paljon hänen autollaan on ajettu ja että hän on hankkimassa uuden auton. Lääkärin käyttämä tulla ajettua -rakenne onkin kakkoskielisen puhujan näkökulmasta varsin monimutkainen, ja painotukset sanoissa kuinka, autoa ja ajettua saattavat osaltaan ohjata potilasta tulkitsemaan kysymyksen väärin. Kysymyksen toinen versio ajatko paljo autoa (rivillä 8) on selkeämpi. Kysymisen kohteeksi hahmottuu ajamisen paljous, ja vaihtoehtokysymys ohjaa potilasta vastaamaan joko kyllä tai ei. Potilas tuottaa halutunlaisen vastauksen.

Esimerkki paljastaa myös jotain olennaista siitä, kuinka kielieroon voidaan vastaanotoilla suhtautua ja kuinka institutionaalinen asetelma vaikuttaa yhteisymmärryksen rakentamisen tapaan. Kieleen liittyviä ongelmia ei nimittäin nosteta keskustelussa käsiteltäviksi, vaan ne pyritään usein ylittämään mahdollisimman huomaamattomasti. Kun esimerkin potilas alkaa kertoa autostaan, lääkäri nyökkäilee ja tuottaa jatkamaan kannustavan minimipalautteen $m$ ? ja hyväksyvän minimipalautteen joo (rivit 5 ja 7 ). Kun potilaan vuoro loppuu, lääkäri esittää kysymyksensä uudelleen ilman merkkejä siitä, että kyse olisi samasta asiasta ja että potilaan tulisi korjata vastaustaan. Lääkäri ei siis aloita torjumalla. Hän ei esimerkiksi sano eiku kuinka paljon sinä ajat tai ei vaan mä tarkotin että ajatko sä paljon. Hyväksyessään epärelevantin vastauksen sellaisenaan lääkäri säästää potilaan kiusalliselta tilanteelta (vrt. en passant repair, Kurhila 2006: 39-43). Potilaan kielitaito ei kyseenalaistu, eikä tämän vastausta henkilökohtaiseen kysymykseen osoiteta vääränlaiseksi.

Huomionarvoista on, että vaikka kieliero huomioidaan vastaanotoilla monin tavoin, kielen oppimiseen ja opettamiseen ei suuntauduta näkyvästi juuri lainkaan (vrt. Lilja 2010). Tämä on sikäli ymmärrettävää, että mahdollisimman sujuva ja häiriötön eteneminen on lääkärin vastaanotolla tärkeää. Keskustelun pääasiallinen tavoite on vastata käynnin syyhyn ja potilaan huoleen, ja kullekin vastaanotolle on varattu rajallisesti aikaa. Kieltä voi oppia samalla, mutta se on sivuseikka.

Vaikka vastaanottokeskustelu ei tarjoakaan erityisen hyviä mahdollisuuksia keskittyä kieliasioihin, sen vakiintunut rakenne ja roolijako tekevät siitä kuitenkin otollisen kontekstin monikulttuuriseen ja kielellisesti epäsymmetriseen vuorovaikutukseen. Vastaanottokeskustelussa lääkärin ja potilaan puheelle on vakiintuneet paikkansa, mikä luo keskusteluun ennakoitavuutta ja tukee keskusteluun osallistumista. Esimerkiksi päätöksenteko etenee monikulttuurisilla vastaanotoilla aivan samaan tapaan kuin muutenkin: lääkärit aloittavat valtaosan päätöksistä, ja potilaat hyväksyvät aloitteet tai vastustavat niitä. Erimielisissä tilanteissa päätöksistä neuvotellaan kuten lääkärin vastaanotolla yleensäkin: lääkärit vetoavat lääketieteellisen asiantuntemukseensa ja potilaat henkilökohtaisiin kokemuksiinsa ja mieltymyksiinsä.

Niin kutsuttua potilaskeskeistä työotetta (ks. King \& Hoppe 2013), jossa potilaan näkökulma huomioidaan tämän hoidossa, voidaan tutkimukseni perusteella ylläpitää myös monikulttuurisilla ja tulkatuilla vastaanotoilla. Siinä missä aiemmat tutkimukset ovat usein tuoneet esiin seikkoja, joiden vuoksi tulkkaus voi heikentää potilaan huomioimista vastaanotoilla (esim. Hsieh 2007), väitöstutkimukseni analysoi keinoja, 
joilla tulkki voi päinvastoin tukea potilaskeskeisyyttä. Tulkki voi esimerkiksi ilmentää kuuntelua ja vaikuttaa potilaan saamaan tilaan keskustelussa sekä osallistua vuorovaikutukseen kehollisesti. Käsittelemäni vuorovaikutuskeinot havainnollistavat tulkin roolia inhimillisenä toimijana ja kyseenalaistavat osittain ihanteen, jonka mukaan hyvä tulkki on keskustelun ulkopuolinen käännöskone.

Kaiken kaikkiaan sekä kieli- ja kulttuurierot että vastaanoton institutionaalinen agenda näyttävät saavan aikaan erityistä yhteistyöhakuisuutta. Kielieron johdosta ymmärrystä pyritään osoittamaan ja tukemaan voimakkaasti, ja yhteinen institutionaalinen tavoite saa lääkärit, potilaat ja tulkit suuntautumaan sujuvaan ja protokollan mukaiseen etenemiseen. Väitöskirjani tulosten perusteella lääkärit ja potilaat näyttävät siis pääsevän monikulttuurisilla vastaanotoilla yhteisymmärrykseen jokseenkin paremmin kuin oletetaan. Voisikin ajatella, että ongelmallinen vuorovaikutus ei välttämättä ole vuorovaikutusta, jossa esiintyy ymmärrysongelmia, vaan vuorovaikutusta, jossa ongelmat jäävät ilmaisematta, havaitsematta tai käsittelemättä tai jossa niitä käsitellään esimerkiksi luottamussuhteen kannalta ongelmallisella tavalla.

Tutkimukseni tulokset eivät tietenkään tarkoita, ettei monikulttuurisilla vastaanotoilla olisi myös epäkohtia ja ettei vuorovaikutuksessa ja palveluissa olisi vielä paljon kehitettävää. Tutkimukseni tuo kuitenkin esille, että kieli- ja kulttuurierot eivät väistämättä johda heikkoihin osallistumismahdollisuuksiin tai eriarvoiseen kohteluun. On asioita, joihin kieli vaikuttaa, ja asioita, joihin kieli ei vaikuta. Asenne sen sijaan vaikuttaa kaikkeen. Monikulttuurinen vuorovaikutus voi sujua siinä missä muunkinlainen, kun siihen osataan asennoitua avoimesti ja kun kieleen ja tietämykseen liittyviä eroja osataan kompensoida keskustelussa. Tutkimukseni tuo tällaista osaamista esille ja mahdollistaa sen hyödyntämisen kieleen, vuorovaikutukseen, tulkkaukseen ja erilaisten kulttuurien kohtaamiseen liittyvissä koulutuksissa ja kehityshankkeissa.

Väitöskirjani anti ei kuitenkaan rajoitu vain monikulttuurisen vuorovaikutuksen teemoihin. Se tuottaa uutta tietoa suomenkielisen keskustelun keinoista. Tutkimukseni valottaa esimerkiksi selittämisen, puheen uudelleenmuotoilun ja päätöksenteon kielellisiä yksityiskohtia ja dynamiikkaa. Lisäksi tutkimukseni tarjoaa keskustelunanalyyttisen ja kielitieteellisen näkökulman lääkärin ammatilliseen läsnäoloon ja havainnollistaa terveydenhuollon vuorovaikutusideologioiden, kuten potilaskeskeisyyden ja yhteisen päätöksenteon, toteuttamista käytännössä.

Yleisemmällä tasolla tutkimukseni havainnollistaa ihmisten välisen yhteisymmärryksen perusmekaniikkaa: vuorovaikutus on mukautumista, erilaisuuden paikkaamista samankaltaisuudella. Tarkastelemmepa lääkäreitä ja potilaita, suomalaisia ja ulkomaalaisia, lapsia ja vanhempia tai toisilleen tuntemattomien satunnaisia kohtaamisia, voimme todennäköisesti havaita samanlaisia elementtejä. Yhteisymmärryksen rakentaminen on kontekstiherkkää, multimodaalista, mukautuvaa, ennakoivaa ja korjaavaa. Väitöstutkimukseni nostaa esiin myös kielellisen ja kehollisen ilmaisun toisiaan täydentävän luonteen. Sillä, että ihmiset voivat nähdä toisensa, liikkua samassa tilassa ja hyödyntää yhteistä materiaalista maailmaa, voi olla yhteisymmärrykselle suurempi merkitys kuin arvaammekaan.

Uskonkin, että ongelmallisempaa kuin se, että keskustelu voi toisinaan vaatia tavallista enemmän vaivannäköä, on se, jos keskustelua ei ole. Yhteiskuntamme on kehitty- 
mässä suuntaan, jossa inhimillisiä kohtaamisia on yhä vähemmän. Opiskelijat seuraavat luentoja kotoa käsin, robotit jakavat vanhusten lääkkeet, ostokset maksetaan itsepalvelukassalla, ja terveysasemalla on vastassa ilmoittautumisautomaatti. Etäyhteydet ja sähköiset järjestelmät ovat hienoja keksintöjä, joiden ansiosta säästetään resursseja ja tavoitetaan aiempaa suurempi joukko ihmisiä. On kuitenkin tärkeää muistaa, ettei niillä suinkaan tavoiteta kaikkia, sillä kirjallisen kielitaidon ja teknisen osaamisen vaatimukset ovat monelle liian korkeat. Järjestelmän kanssa kommunikoiminen ei myöskään vastaa ihmiskontaktia. Yhdenvertaisuuden ja sosiaalisten suhteiden näkökulmasta on tärkeää pitää huoli siitä, että asioita voi jatkossakin hoitaa myös kasvotusten ihmisten kanssa. Olen kiitollinen, että seuraava väittely käydään perinteiseen tapaan keskustelemalla luentosalissa.

\section{Kirjallisuus}

Aalto, Anna-Mari - Elovainio, Marko - Heponiemi, Tarja - Hietapakka, LAURA - KuUSIO, HANNAMARIA - LäMSÄ, RiıkKA2013: Ulkomaalaistaustaiset lääkärit ja hoitajat suomalaisessa terveydenhuollossa. Haasteet ja mahdollisuudet. - Raportti 7/2013. Helsinki: THL. http://urn.fi/URN:ISBN:978-952-245-857-5.

Castaneda, Anu - Larja, Lissa - Nieminen, Tarja - Jokela, Satu - Suvisaari, JaAna - Rask, Shadia - Koponen, Pärvikki - Koskinen, Seppo 2015: Ulkomaalaistaustaisten psyykkinen hyvinvointi, turvallisuus ja osallisuus - Ulkomaista syntyperää olevien työ ja hyvinvointi -tutkimus 2014 (UTH). Helsinki: THL. http://urn.fi/ URN:ISBN:978-952-302-535-6.

Hsieh, Elaine 2007: Interpreters as co-diagnosticians. Overlapping roles and services between providers and interpreters. - Social Science \& Medicine 64 s. 924-937. https://doi. org/10.1016/j.socscimed.2006.10.015.

King, Anne - Hoppe, Ruth 2013: "Best practice" for patient-centered communication: A narrative review. - Journal of Graduate Medical Education 5 s. 385-393. https://doi. org/10.4300/JGME-D-13-00072.1.

Kurhila, SAlla 2006: Second language interaction. Philadelphia: John Benjamins. https:// doi.org/10.1075/pbns.145.

LILJA, NiIna 2010: Ongelmista oppimiseen. Toisen aloittamat korjausjaksot kakkoskielisessä keskustelussa. Jyväskylä studies in humanities 146. Jyväskylän yliopisto.

LÄ̈̈KÄ RILIIT TO 2017: Lääkärit 2016. Lääkäriliiton vuositilasto 2016. https://www.laakariliitto. fi/site/assets/files/1268/1116_tilasto2016_net1_170114.pdf (1.3.2019)

Malin, Maili - SuvisaAri, JAAna 2010: Maahanmuuttajien terveys ja hyvinvointi. - Antti Pakaslahti \& Matti Huttunen (toim.), Kulttuurit ja lääketiede s. 134-163. Helsinki: Duodecim.

Paananen, Jenny 2015: Kuinka eleet helpottavat yhteisymmärrystä? Ikoniset ja deiktiset eleet monikulttuurisilla lääkärin vastaanotoilla. - Puhe ja kieli 35 s. 73-95. https://journal.fi/pk/ article/view/51354.

— 2016: Kuinka lääkärit korjaavat kysymyksiään? Kysymysten uudelleenmuotoilu monikulttuurisilla lääkärin vastaanotoilla. - Virittäjä 120 s. 552-579. https://journal.fi/virittaja/ article/view/52766.

— 2017: Kuinka lääkärit selittävät asiantuntijainformaatiota? Selittäminen vuorovaikutuksel- 
lisena, kielellisenä ja kehollisena toimintana monikulttuurisilla vastaanotoilla. - Puhe ja kieli 37 s. 119-144. https://doi.org/10.23997/pk.66755.

— 2018: Päätöksentekokeskustelu monikulttuurisilla lääkärin vastaanotoilla. - Sosiaalilääketieteellinen Aikakauslehti 55 s. 287-308. https://doi.org/10.2399o/sa.6698o.

Paananen, Jenny - Majlesi, Ali Reza 2018: Patient-centered interaction in interpreted primary care consultations. - Journal of Pragmatics 138 s. 98-118. https://doi.org/10.1016/j. pragma.2018.10.003.

SVT 2018 = Suomen virallinen tilasto. Väestöennuste. Helsinki: Tilastokeskus. http://www.stat. fi/til/vaenn/2018/vaenn_2018_2018-11-16_tie_oo1_fi.html (11.2.2019).

Tervola, MaIja 2017: Työelämän näkökulma maahanmuuttajataustaisten lääkärien kielitaitoon. - Sosiaalilääketieteellinen Aikakauslehti 54 s. 196-208. https://doi.org/10.2399o/ sa.65564.

Jenny Paananen: Yhteisymmärryksen rakentaminen monikulttuurisilla lääkärin vastaanotoilla. Turun yliopiston julkaisuja - Annales Universitatis Turkuensis C 465. Turku: Turun yliopisto 2019. Artikkeliväitöskirjan yhteenveto-osa on luettavissa osoitteessa http://urn.fi/URN:ISBN:978-951-29-7557-0

Kirjoittajan yhteystiedot:

jekrni@utu.fi 